\title{
Chemical composition and sensory analysis of roasted peanuts coated with prickly pear and algarrobo pod syrups
}

\author{
By V. Nepote ${ }^{2}$, M. G. Mestrallet ${ }^{1}$, R. H. Olmedo', L. C. Ryan ${ }^{3}$, S. Conci ${ }^{3}$ and N. R. Grosso ${ }^{1 *}$ \\ ${ }^{1}$ Química Biológica, Facultad de Ciencias Agropecuarias (UNC), IMBIV-CONICET, \\ CC 509, 5000 Córdoba, Argentina. \\ ${ }^{2}$ ICTA, Facultad de Ciencias Exactas, Físicas y Naturales, IMBIV-CONICET, Córdoba, Argentina. \\ ${ }^{3}$ Escuela de Nutrición, Facultad de Ciencias Médicas (UNC), Córdoba, Argentina. \\ * Corresponding autor: nrgrosso@agro.uncor.edu
}

\section{RESUMEN}

Análisis químico y sensorial de maní tostado cubierto con arrope de tuna y de algarrobo.

El objetivo del trabajo fue determinar la composición química, atributos sensoriales y la aceptabilidad del maní tostado cubierto con arrope de tuna (RP-P) y de Algarrobo (RP-A). El maní tostado sin cobertura presentó el mayor contenido de aceite $(50,4 \%)$ en comparación con los maníes cubiertos, RPP y RP-A ( $45,3 \%$ y $46,7 \%$, respectivamente). RP-P y RP-A mostraron menor porcentaje de proteína y mayor contenido de hidratos de carbonos que RP. Estos resultados afectaron los valores energéticos de los productos: $6,14 \mathrm{kcal} / \mathrm{g}$ in RP-P, $6,24 \mathrm{kcal} / \mathrm{g}$ in RP-A y $6,42 \mathrm{kcal} / \mathrm{g}$ in RP. En la prueba de consumidores, RP y RP-P tuvieron mayor aceptabilidad para los atributos color, textura y sabor que en RP-A. En la prueba descriptiva, RP-P y RP-A mostraron mayores intensidades en los atributos sensoriales de color marrón, rugosidad, brillo, pulverulencia, dulzor y salado y menor intensidad en sabor crudo/poroto que en RP. Las intensidades del sabor a maní tostado y de los atributos de texturas en el análisis descriptivo no fueron afectadas por la presencia de la cobertura de arrope.

PALABRAS-CLAVE: Aceptabilidad - Algarrobo - Arrope - Maní - Sensorial - Tuna.

\section{SUMMARY}

Chemical composition and sensory analysis of roasted peanuts coated with prickly pear and algarrobo pod syrups.

The objective of this work was to determine the chemical composition, sensory attributes and consumer acceptance of roasted peanuts coated with prickly pear (RP-P) and "algarrobo" pod syrups (RP-A). Roasted peanuts (RP) without coating had the highest oil content (50.4\%) in comparison with the coated products RP-P and RP-A (45.3\% and $46.7 \%$, respectively). RP-P and RP-A showed lower protein percentage and higher carbohydrate content than RP. These results affected the energy values of the products: $6.14 \mathrm{kcal} / \mathrm{g}$ in RP-P, $6.24 \mathrm{kcal} / \mathrm{g}$ in RP-A and 6.42 $\mathrm{kcal} / \mathrm{g}$ in RP. In the consumer test, RP and RP-P had higher consumer acceptance for the attributes of color, texture and flavor than RP-A. In the descriptive analysis, RP-P and RPA showed higher intensity ratings in brown color, roughness, glossy, powdery, sweetness, and salty sensory attributes and lower intensity ratings in raw/beany flavor than in RP. The intensity of roasted peanutty flavor and the texture attributes in the descriptive analysis were not affected for the pod syrup coating.

KEY-WORDS: Acceptability - Algarrobo - Peanuts Prickly pear - Sensory.

\section{INTRODUCTION}

Peanut-containing foods had high consumer acceptance because of their unique roasted peanut flavor. Peanuts are continually applied for the preparation of new and improved food products (Woodroof, 1983). A large proportion of peanut production in the world is destined to domestic foods such as peanut butter, salted peanut products, confections, and roasted. The rest of the peanut production is utilized as an edible oil source of high quality (Ahmed and Young, 1982).

Peanut kernels contain approximately 50-55\% oil, $25-28 \%$ protein, $19-21 \%$ carbohydrates and 2.3$2.5 \%$ ashes (Grosso and Guzman, 1995). Due to their high matter content, peanuts are rich in energy but are susceptible to developing rancidity and off-flavours through lipid oxidation because of their composition rich in polyunsaturated fatty acid with $30-35 \%$ and $45-50 \%$ of the oil being linoleic and oleic acids, respectively (St Angelo, 1996; Frankel, 2005). Edible coatings in peanut products may prevent moisture loss and oxygen diffusion and be used as a vehicle for additives such as antioxidants and flavoring agents and improve consumer acceptance for applying flavoring (Grosso and Resurreccion, 2002). In this sense, coatings with a high content of carbohydrate are an alternative. In previous works, honey was used in the coating showing positive results in relation to consumer acceptance and sensory and chemical stability (Nepote et al., 2004; Mestrallet et al., 2004; Nepote et al., 2006b).

Prickly pear (Opuntia ficus-indica) is original from Mexico and the Caribbean and has 
importance in arid regions of Argentina because of its adaptability potential to different environmental conditions without cultivation care. Many products and sub-products are obtained from this specie. It is used in Argentina as forage in animal feeding and food for human consumption such as fresh fruit and cooked products (syrup, jelly and marmalade). Some prickly pear products also have medicinal properties (cough treatment, flower infusion as diuretic). The fresh fruits have the following composition: $0.8 \%$ protein, $0.7 \%$ lipids, $0.19 \%$ pectin, $0.1 \%$ fiber, $6 \%$ carbohydrates, $90 \%$ water and $60 \mathrm{mg} / 100 \mathrm{~g}$ fruit vitamin C. For producing pod syrup, the fruits are processed by cooking the juice until the sugar is concentrated, then a sweet and dark syrup called "arrope de tuna" is prepared. Its consistence is similar to honey and has a sweet flavor and high energy value. This is a traditional, artisan product consumed on a low scale by regional people from Argentina (Demaio et al., 2002).

The Algarrobo tree (Prosopis spp) is found in America, Africa and West Asia. In Argentina, the Prosopis specie is located in the western and central arid regions of the country. The pods have $6 \%$ moisture, $59 \%$ carbohydrates, $9 \%$ proteins, $3 \%$ lipids, $20 \%$ fiber, $3 \%$ ashes, $0.3 \%$ calcium and $0.1 \%$ phosphorous. The fruits of the Algarrobo are edible for human beings. Because of their high sugar content, different products were obtained from the pods. One of them is a kind of flour called "patay" in Argentina. Another product elaborated with the fruit is a kind of syrup called "arrope de algarrobo". This dark and thick syrup is obtained by boiling the pods until the sugars of the fruit are concentrated (Astudillo et al., 2000; Demaio et al., 2002).

The objective of this work was to determine the chemical composition, sensory attributes and consumer acceptance of roasted peanuts coated with prickly pear and "algarrobo" pod syrups.

\section{MATERIALS AND METHODS}

\subsection{Materials}

Sound, mature seeds of blanched peanuts (Arachis hypogaea L.) type Runner, size 38/42 kernels per oz (2004 crop) were provided by the company, Lorenzati, Ruetsch y Cia from Ticino, Córdoba province, Argentina. Before processing, peanuts were inspected and damaged or bruised kernels were manually removed.

Syrups (in Spanish called "Arropes") elaborated from fruits of Opuntia ficus-indica (prickly pear) and Prosopis nigra (algarrobo negro) were provided by the Company "Gran Diet", Córdoba, Argentina.

\subsection{Product Elaboration}

Roasted peanuts (RP). Blanched peanuts were roasted at $140{ }^{\circ} \mathrm{C}$ in an oven (Memert, model 600 , Schwabach, Germany) for $30 \mathrm{~min}$. Peanuts were heated to a medium roast measured as an average Hunter color Lightness (L) value of $50 \pm 1.0$ (Johnsen et al., 1988).

Roasted peanuts coated with prickle pear pod syrup (RP-P). This product was prepared with $85 \%$ RP and $5 \%$ prickle pear pod syrup and $10 \%$ dried-solid mixture (w/w/w). A dried-solid mixture was elaborated with $70 \%$ impalpable sucrose, $20 \%$ impalpable salt and $10 \%$ corn starch (w/w/w). RP were placed into the stainless steel coating pan rotating at $28 \mathrm{rpm}$. Then the syrup was applied to the RP. Finally, the dried-solid mixture was poured onto the coating pan to separate the kernels.

Roasted peanuts coated with "algarrobo" pod syrup (RP-A). This product was prepared using the same procedure described for RP-P: $85 \%$ $\mathrm{RP}, 5 \%$ "algarrobo" pod syrup and $10 \%$ dried-solid $\operatorname{mix}(w / w / w)$.

\subsection{Determination of oil, ash, protein, and carbohydrate contents of the peanut products}

Three samples $(5 \mathrm{~g})$ from each peanut product (RP, RP-P and RP-A) were examined for moisture, lipid, protein, ash and carbohydrate contents. The kernels were selected at random. The moisture content was determined by the method 27.005 (AOAC, 1980). Kernels were milled and the oil was extracted for $16 \mathrm{~h}$ with petroleum ether (boiling range $30-60{ }^{\circ} \mathrm{C}$ ) in a Soxhlet apparatus. The lipid percentage was determined by weight difference. Ash and nitrogen contents were determined according to the AOAC methods 27.009 and 27.007, respectively (AOAC, 1980). Ash was performed by incineration in a muffle furnace at $525{ }^{\circ} \mathrm{C}$. The nitrogen content was estimated according to the Kjeldahl method and converted to protein percentage by using the conversion factor 5.46 (method 27.007, AOAC, 1980). The carbohydrate content was estimated by calculating its difference from the other components using the following formula (Mestrallet et al., 2004): carbohydrate content $=100 \%-(\%$ protein $+\%$ oil + $\%$ ash).

\subsection{Sensory Methods}

a) Consumer Analysis. The panellists $(n=100)$ were from Cordoba (Argentina) and were recruited according to the following criteria: a) ages between 18 and 65, b) non-smokers, c) people without food allergies and d) people who consumed roasted peanuts and/or peanut products at least twice a week. For sample evaluation, $5 \mathrm{~g}$ of the peanut samples were placed into plastic cups with lids coded with 3 digit random numbers. Samples consisting of fresh RP, RP-P and RP-A (3 replicates of each) were served to each panelist (Resurreccion, 1998). Samples were presented to panellists in random order during the test day. Samples were presented with water and paper 
ballots on a plastic tray. Panellists were instructed to consume the whole sample and rinse their mouths with water between samples to minimize any residual effect (Grosso and Resurreccion, 2002). A 5 -point hedonic scale ranging from $1=$ dislike it very much to 5 = like it very much was used to evaluate acceptance from the RP, RP-P and RP-CB samples for the attributes of color, texture and flavor (Meilgaard et al., 1991).

b) Descriptive Analysis. A total of 12 trained panellists ( 9 female and 3 male) participated for the descriptive analysis of peanut products (RP, RP-P and RP-A). All panellists had 4 years of experience evaluating peanut products and were selected according to the following criteria: a) people with natural dentition, b) people without food allergies, c) non-smokers, d) people between the ages of 18-64, e) people who consume roasted peanuts and/or peanut products at least once a month, f) people available for all sessions, g) people interested in participating, and h) people able to verbally communicate their observations regarding the product (Plemmons and Resurreccion, 1998). Before being qualified, all panellists showed a perfect score in a taste sensitivity test and the ability to identify 5 of 7 commonly found food flavors.

All 12 panellists were trained and participated in 4 training sessions over 4 days. Each training session lasted $2 \mathrm{~h}$. Descriptive analysis test procedures as described by Meilgaard et al. (1991), Grosso and Resurreccion (2002) and Nepote et al. (2006a) were followed to train the panellists. Panellists evaluated samples using a "hybrid" descriptive analysis method consisting of the Quantitative Descriptive Analysis (Tragon Corp.,
Redwood City, Calif., U.S.A.) and the Spectrum ${ }^{\mathrm{TM}}$ Analysis Methods (Sensory Spectrum, Inc., Chatham, N.J., U.S.A.). A $150 \mathrm{~mm}$ unstructured line scale was used (Plemmons and Resurreccion, 1998). A list of definitions (Table 1) and a sheet with warm-up and reference intensity ratings (Table 2) were developed during the training sessions (Grosso and Resurreccion, 2002; Mestrallet et al., 2004). The attribute definitions were based on a peanut lexicon (Johnsen et al., 1988).

All samples were evaluated in partitioned booths under fluorescent light at room temperature. Ten grams of product sample were placed into plastic cups with lids coded with 3 digit random numbers. Panellists evaluated 12 samples per day plus a warm-up sample. The final lists of warm-up and reference intensity ratings and definitions (Table 1 and 2) were posted in the booths for all test sessions (Grosso and Resurreccion, 2002). Samples were tested using a complete randomized block design. The data were registered on paper ballots.

\subsection{Statistical Analysis}

The data were analyzed using the InfoStat software, version 1.1 (Facultad de Ciencias Agropecuarias, Universidad Nacional de Córdoba). All analyses were performed in three repetitions. Means and standard deviations were calculated. Analysis of variance and Duncan test were used to detect significant differences $(\alpha=0.05)$ in consumer responses, sensory attribute ratings and chemical analysis measurements.

Table 1

Definitions of attributes to describe roasted peanuts and roasted peanuts coated with prickly pear and "algarrobo" pod syrups

\begin{tabular}{|c|c|}
\hline Attribute $^{a}$ & Definition \\
\hline $\begin{array}{l}\text { Appearance } \\
\text { 1- Brown Color } \\
\text { 2- Roughness } \\
\text { 3- Glossy } \\
\text { 4- Powdery }\end{array}$ & $\begin{array}{l}\text { The intensity or the strength of brown color from light to dark brown. } \\
\text { The appearance associated with uneven surface. } \\
\text { The appearance associated with the amount of light reflected by the product surface. } \\
\text { The appearance associated with the amount of powder particles on the surface. }\end{array}$ \\
\hline $\begin{array}{l}\text { Aromatics } \\
\text { 5- Roasted Peanutty } \\
\text { 6- Oxidized } \\
\text { 7- Cardboard } \\
\text { 8- Raw/Beany }\end{array}$ & $\begin{array}{l}\text { The aroma associated with medium roasted peanuts. } \\
\text { The aroma associated with rancid fats and oils. } \\
\text { The aroma associated with wet cardboard. } \\
\text { The aroma associated with raw peanuts having green bean character. }\end{array}$ \\
\hline $\begin{array}{l}\text { Tastes } \\
\text { 9- Sweetness } \\
\text { 10- Salty } \\
\text { 11- Sour } \\
\text { 12- Bitterness }\end{array}$ & $\begin{array}{l}\text { Taste on the tongue associated with sucrose solutions. } \\
\text { Taste on the tongue associated with sodium chloride solutions. } \\
\text { Taste on the tongue associated with acidic agents such as citric acid solutions. } \\
\text { Taste on the tongue associated with bitter solutions such as caffeine. }\end{array}$ \\
\hline $\begin{array}{l}\text { Texture } \\
\text { 13- Hardness } \\
\text { 14- Crunchiness } \\
\text { 15- Tooth Pack }\end{array}$ & $\begin{array}{l}\text { Force needed to compress a food between molar teeth. } \\
\text { Force needed and amount of sound generated from chewing a sample with molar teeth. } \\
\text { The amount of sample left in or on teeth after chewing. }\end{array}$ \\
\hline
\end{tabular}

\footnotetext{
${ }^{a}$ Attributes listed in order as perceived by panelists.
} 
Table 2

Standard reference and warm up intensity ratings used in the descriptive analyses of roasted peanuts and roasted peanuts coated with prickly pear and "algarrobo" pod syrups

\begin{tabular}{|c|c|c|c|}
\hline Attribute & Reference & Reference intensity ${ }^{a}$ & Warm up intensity ${ }^{a, b}$ \\
\hline \multicolumn{4}{|l|}{ Appearance } \\
\hline 1- Brown Color & Cardboard. & 46 & 38 \\
\hline 2- Roughness & Corn flakes (Granix, Buenos Aires, Argentina). & 93 & 36 \\
\hline 3- Glossy & White Bean (Salta, Argentina) & 64 & 15 \\
\hline 4- Powdery & $\begin{array}{l}\text { Blanched Peanuts (Lorenzati, Ruestch y CIA, } \\
\text { Córdoba, Argentina) with } 5 \% \text { wheat flour. }\end{array}$ & 79 & 11 \\
\hline \multicolumn{4}{|l|}{ Aromatics } \\
\hline 5- Roasted Peanutty & $\begin{array}{l}\text { Dry roasted peanuts (JL SA, Ticino, Cordoba, } \\
\text { Argentina). }\end{array}$ & 69 & 57 \\
\hline 6- Oxidized & Rancid peanuts. & 82 & 6 \\
\hline 7- Cardboard & Moist cardboard. & 66 & 12 \\
\hline 8- Raw/Beany & $\begin{array}{l}\text { Raw blanched peanuts (Lorenzati, Ruestch } \\
\text { y CIA, Córdoba, Argentina). }\end{array}$ & 75 & 17 \\
\hline \multicolumn{4}{|l|}{ Tastes } \\
\hline 9- Sweetness & $\begin{array}{l}2 \% \text { sucrose solution. } \\
5 \% \text { sucrose solution. } \\
10 \% \text { sucrose solution. } \\
15 \% \text { sucrose solution. }\end{array}$ & $\begin{array}{r}20 \\
50 \\
100 \\
150\end{array}$ & 17 \\
\hline 10- Salty & $\begin{array}{l}0.2 \% \mathrm{NaCl} \text { solution. } \\
0.35 \% \mathrm{NaCl} \text { solution. } \\
0.5 \% \mathrm{NaCl} \text { solution. }\end{array}$ & $\begin{array}{l}25 \\
50 \\
85\end{array}$ & 12 \\
\hline 11-Sour & $\begin{array}{l}0.05 \% \text { citric acid solution. } \\
0.08 \% \text { citric acid solution. } \\
0.15 \% \text { citric acid solution. }\end{array}$ & $\begin{array}{r}20 \\
50 \\
100\end{array}$ & 7 \\
\hline 12- Bitterness & $\begin{array}{l}0.05 \% \text { caffeine solution. } \\
0.08 \% \text { caffeine solution. } \\
0.15 \% \text { caffeine solution. }\end{array}$ & $\begin{array}{r}20 \\
50 \\
100\end{array}$ & 9 \\
\hline \multicolumn{4}{|l|}{ Texture } \\
\hline 13- Hardness & Almonds (Grandiet, Córdoba, Argentina). & 69 & 47 \\
\hline 14- Crunchiness & Corn flakes (Granix, Buenos Aires, Argentina). & 110 & 62 \\
\hline 15- Tooth Pack & $\begin{array}{l}\text { Raw Blanched Peanuts (Lorenzati, Ruestch y } \\
\text { CIA, Córdoba, Argentina). }\end{array}$ & 90 & 55 \\
\hline
\end{tabular}

${ }^{a}$ Intensity ratings are based on $150 \mathrm{~mm}$ unstructured line scales. ${ }^{\mathrm{b}}$ Medium (lightness value, $\mathrm{L}=50 \pm 1$ ) roasted peanuts (Blanched, size 40/50, type Runner).

\section{RESULTS AND DISCUSSION}

\subsection{Oil, ash, protein, and carbohydrate contents in the peanut products}

Peanuts contain about 50 to $55 \%$ oil and 25 to $28 \%$ protein (Ahmed and Young, 1982). For this reason, peanuts make an important contribution to the human diet in many countries for their nutritional benefits to consumers. Therefore, it is important to known the chemical composition of a peanut product. The oil, protein, ash and carbohydrate contents of the roasted peanuts and roasted peanuts coated with prickly pear and "algarrobo" pod syrups are presented in Figure 1. The products coated with syrup (RP-P and RP-A) showed significant differences $(\alpha=0.05)$ in protein, oil and carbohydrate contents with respect to RP. Roasted peanuts had the highest oil content $(50.4 \%)$ in comparison with the coated products RP-P and RPA (45.3\% and $46.7 \%$, respectively). RP-P and RP-A showed lower protein contents $(24.6 \%$ and $24.1 \%$, respectively) than $\mathrm{RP}(27.0 \%)$. On the contrary, RP$\mathrm{P}$ and RP-A had higher carbohydrate contents (27.3\% and $26.9 \%$, respectively) than RP $(20.3 \%)$. These differences observed in the chemical composition of the products were statistically significant. The coating layer for RP-P and RP-A was $15 \%$ ( $5 \%$ pod syrup $+10 \%$ dried-solid mix). This layer is rich in carbohydrates constituted by sugar and pod syrups. This coating layer composition affected the chemical composition of the products making RP-P and RP-A higher in carbohydrate content and lower in protein and oil percentages. In addition, these results affected the energy values of the products. Lipids are the main 


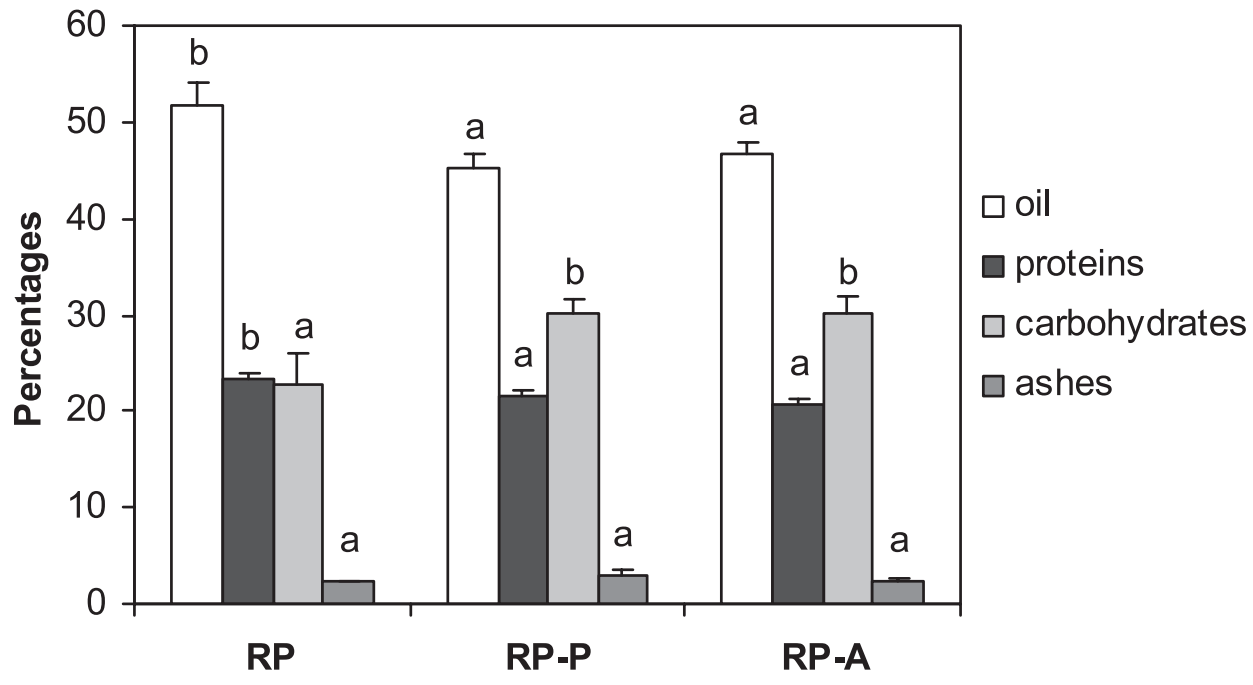

Figure 1

Oil, protein, ash and carbohydrate percentages in roasted peanuts (RP) and roasted peanuts coated with prickly pear (RP-P) and "algarrobo" (RP-A) pod syrups.

${ }^{*}$ Bar of the same component with the same letter among peanut products are not significantly different at $\alpha=0.05$.

source of calories; so RP-P (6.14 kcal/g) and RP-A $(6.24 \mathrm{kcal} / \mathrm{g})$ had lower energy values than $\mathrm{RP}$ $(6.43 \mathrm{kcal} / \mathrm{g})$. Mestrallet et al. (2004) reported similar results in roasted peanuts coated with honey (honey roasted peanuts) where the protein, lipid and carbohydrates contents were $22.06 \%, 45.6 \%$ and $28.22 \%$, respectively.

\subsection{Consumer Analysis}

Consumer testing is one of the most important activities in product development. The primary purpose of consumer testing is to assess the personal response by current and potential customers of a product, product ideas, or specific product characteristics. Consumer evaluation concerns itself with testing certain products using untrained people who are or will become the ultimate users of the product. Consumer testing is necessary throughout the various stages of the product cycle. These stages include the development of the product itself, product maintenance, product improvement and optimization, and assessment of market potential (Resurreccion, 1998). In this study, the consumer test was conducted to detect differences between products. The answer percentage means for each point in the hedonic scale of flavor, color and texture acceptance and general averages from the consumer test for RP and RP-P and RP-A are presented in Table 3. For flavor acceptance, significant differences $(\alpha=0.05)$ in the answer percentage means were found between the products in points 1 (dislike very much) and 5 (like very much) on a 5-point hedonic scale. The answer percentages in point 5 were higher for RP. The flavor acceptance mean (general average) was higher for RP and significantly different with respect to RP-A. In color acceptance, significant differences in the answer percentage means were found between the products in points 1 (dislike very much), 2 (dislike moderately), 3 (neither like nor dislike) and 5 (like very much) on a 5-point hedonic scale. The answer percentages in points 3 and 5 were higher for RP. The color acceptance mean (general average) was higher for $\mathrm{RP}$ and significantly different with respect to RP-A. In texture acceptance, significant differences in the answer percentage means were found between the products in all points of the 5-point hedonic scale. In general, the texture acceptance (general average) was higher for RP and significantly different with respect to RP-A.

The results of the consumer test showed that the roasted peanuts coated with pod syrups (RP-P and RP-A) have good acceptability for flavor, color and texture acceptance in the consumer test because the acceptability of the flavor, color and texture attributes were higher than point 3 (neither like nor dislike) on the hedonic scale of 5 points. The pod syrup ("arrope") from prickly pear and "algarrobo" is a traditional food in the northwest of Argentina. People in that Argentinean region have high preference for this food. People from other Argentinean regions have not developed the liking for pod syrups. For this reason, these people do not have preference for this flavor. The province of Córdoba is between the northwest and the center of Argentina. Probably, the diversity of preference in people from this area lead to a variable rating on the 5-point hedonic scale from the consumer test. In this work, it was observed that some consumer panellists gave high ratings to roasted peanuts coated with pod syrups in the consumer test and these same panelists gave lower ratings to roasted peanuts without coating and viceversa; some 
Table 3

Means of answer percentage for each point in hedonic scale and general average of the flavor, color and texture acceptance from consumer tests of roasted peanuts (RP) and roasted peanuts coated with prickly pear (RP-P) and "algarrobo" (RP-A) pod syrups

\begin{tabular}{|c|c|c|c|}
\hline & RP & RP-P & RP-A \\
\hline \multicolumn{4}{|l|}{ For flavor } \\
\hline 1- Dislike Very Much ${ }^{1,2}$ & $8.67 \pm 0.75 a$ & $11.33 \pm 2.72 b$ & $12.00 \pm 2.15 b$ \\
\hline 2- Dislike Moderately ${ }^{1,2}$ & $10.33 \pm 1.62 a$ & $12.67 \pm 2.16 a$ & $14.67 \pm 2.72 \mathrm{a}$ \\
\hline 3- Neither Like nor Dislike ${ }^{1,2}$ & $20.00 \pm 3.89 a$ & $23.00 \pm 3.62 a$ & $28.67 \pm 3.79 a$ \\
\hline 4- Like Moderately ${ }^{1,2}$ & $24.67 \pm 3.56 a$ & $25.33 \pm 3.27 a$ & $23.33 \pm 3.12 a$ \\
\hline 5- Like Very Much ${ }^{1,2}$ & $36.33 \pm 4.89 a$ & $27.67 \pm 3.19 a b$ & $21.33 \pm 2.99 b$ \\
\hline General Average 2,3 & $3.71 \pm 1.28 \mathrm{a}$ & $3.45 \pm 1.53 a b$ & $3.27 \pm 1.47 b$ \\
\hline \multicolumn{4}{|l|}{ For color } \\
\hline 1- Dislike Very Much ${ }^{1,2}$ & $2.67 \pm 0.27 a$ & $8.33 \pm 2.61 b$ & $10.00 \pm 2.07 b$ \\
\hline 2- Dislike Moderately ${ }^{1,2}$ & $8.33 \pm 2.53 a$ & $8.67 \pm 1.35 a$ & $11.67 \pm 2.43 b$ \\
\hline 3- Neither Like nor Dislike ${ }^{1,2}$ & $35.00 \pm 4.56 a$ & $29.00 \pm 3.97 b$ & $30.67 \pm 4.28 b$ \\
\hline 4- Like Moderately ${ }^{1,2}$ & $23.67 \pm 2.91 \mathrm{a}$ & $27.33 \pm 4.16 \mathrm{a}$ & $24.33 \pm 3.16 a$ \\
\hline 5- Like Very Much ${ }^{1,2}$ & $30.33 \pm 4.73 a$ & $26.67 \pm 3.19 \mathrm{ab}$ & $23.33 \pm 2.08 b$ \\
\hline General Average ${ }^{2,3}$ & $3.71 \pm 1.08 a$ & $3.55 \pm 1.20 a b$ & $3.39 \pm 1.29 b$ \\
\hline \multicolumn{4}{|l|}{ For texture } \\
\hline 1- Dislike Very Much ${ }^{1,2}$ & $3.67 \pm 0.77 a$ & $8.33 \pm 2.81 b$ & $10.00 \pm 2.00 b$ \\
\hline 2- Dislike Moderately ${ }^{1,2}$ & $7.67 \pm 2.53 a$ & $10.33 \pm 2.85 b$ & $11.67 \pm 2.33 b$ \\
\hline 3- Neither Like nor Dislike ${ }^{1,2}$ & $36.00 \pm 4.36 a$ & $26.67 \pm 4.01 b$ & $27.67 \pm 4.08 b$ \\
\hline 4- Like Moderately ${ }^{1,2}$ & $25.33 \pm 3.51 a$ & $31.00 \pm 4.27 b$ & $27.33 \pm 3.53 \mathrm{ab}$ \\
\hline 5- Like Very Much ${ }^{1,2}$ & $27.33 \pm 4.53 a$ & $23.67 \pm 3.79 \mathrm{ab}$ & $22.33 \pm 3.08 b$ \\
\hline General Average $^{2,3}$ & $3.65 \pm 1.04 a$ & $3.51 \pm 1.18 \mathrm{ab}$ & $3.36 \pm 1.29 b$ \\
\hline
\end{tabular}

${ }^{1}$ Hedonic scale of 5 points (Meilgard et al 1991). ${ }^{2}$ Mean followed by the same letter within each row are not significantly different at $\alpha=$ $0.05 .^{3}$ General averages corresponding to the mean value from the all consumer answers in a hedonic scale of 5 points.

consumer panellist gave high ratings to $\mathrm{RP}$ and lower ratings to RP-P and RP-A. In other works, higher overall acceptance in other peanut products like cracker coated peanuts (Grosso and Resurreccion, 2002) and honey roasted peanuts (Mestrallet et al., 2004) were also found.

\subsection{Descriptive Analyses}

The mean values of the sensory attribute intensities from the descriptive analysis in RP, RP-P and RP-A are presented in Table 4. Fifteen sensory attributes were described by the panellists of the trained sensory panel in the peanut products analyzed. The attributes are the following: for appearance: brown color, roughness, glossy and powdery; for aroma: roasted peanutty, oxidized, cardboard and raw/beany; for taste: sweetness, salty, bitterness and sour; and for texture: hardness, crunchiness and tooth pack.

The samples showed significant differences $(\alpha=$ $0.05)$ in some described sensory attributes. RP-P and RP-A showed higher intensity ratings in the following attributes: brown color, roughness, glossy, powdery, sweetness, and salty and lower intensity rating in raw/ beany flavor than in RP. RP-A had higher intensity ratings in brown color and lower intensity rating in the glossy appearance attribute and sweet taste than RP-P.

The intensity of roughness and powdery sensory attributes were higher in RP-P and RP-A due to the coating layer of pod syrup with sugar and salt. Roasted peanutty flavor is the attribute used to characterize peanut flavor in peanut products (Johnsen et al., 1988). This attribute did not show significant differences between samples. This result indicates that the intensity of this attribute was not covered up by other attributes like sweet and salty. Mestrallet et al. (2004) found that the intensity of roasted peanutty flavor in honey roasted peanuts was partially covered up by the flavor produced by the ingredients used in the coating layers.

Johnsen et al. (1988) developed a basic lexicon for the description of peanut flavor. The lexicon is intended to provide a means of communication among the peanut grower, the peanut industry, the peanut researcher and the peanut manufacturers. The roasted peanutty attribute is used to characterize the typical roasted peanut flavor. Roasted peanutty flavor can be attributed to the presence of pyrazines (Buckholz and Daun, 1981; Crippen et al., 1992). Bett and Boylston (1992) found that roasted peanutty flavor intensity and alkylpyrazines decreased in stored roasted peanuts. Warner et al. (1996), Brannan et al. (1999) Nepote et al. (2006b) also found that roasted peanutty flavor decreased in stored roasted peanuts. Meilgaard et al. (1991) reported a roasted peanutty intensity of 7 on a scale of $1-15$ points equivalent to 70 on an scale of $0-150$ points measured by a trained panel in roasted peanuts from America. Grosso and Resurreccion (2002) 
Table 4

Means of sensory attribute intensities from descriptive analyses in roasted peanuts (RP) and roasted peanuts coated with prickly pear (RP-P) and "algarrobo" (RP-A) pod syrups

\begin{tabular}{lccc}
\hline \multicolumn{1}{c}{ Sensory atributes } & $\mathbf{R P}^{\mathbf{a}}$ & $\mathbf{R P}^{\mathbf{a}}$ & $\mathbf{R P}^{\mathbf{a}}$ \\
\hline Appearance & & & $29.2 \pm 6.7 \mathrm{C}$ \\
1- Brown Color & $17.3 \pm 3.5 \mathrm{~A}$ & $24.7 \pm 5.5 \mathrm{~B}$ & $49.3 \pm 9.0 \mathrm{~B}$ \\
2- Roughness & $30.9 \pm 7.3 \mathrm{~A}$ & $48.8 \pm 10.8 \mathrm{~B}$ & $17.3 \pm 6.2 \mathrm{~B}$ \\
3- Glossy & $13.7 \pm 4.5 \mathrm{~A}$ & $19.3 \pm 9.5 \mathrm{C}$ & $19.7 \pm 9.0 \mathrm{~B}$ \\
4- Powdery & $8.8 \pm 6.8 \mathrm{~A}$ & $18.4 \pm 7.9 \mathrm{~B}$ & $49.9 \pm 10.4 \mathrm{~A}$ \\
Aromatics & & & $3.8 \pm 3.2 \mathrm{~A}$ \\
5- Roasted Peanutty & $51.4 \pm 11.9 \mathrm{~A}$ & $49.4 \pm 9.8 \mathrm{~A}$ & $6.5 \pm 6.1 \mathrm{~A}$ \\
6- Oxidized & $3.6 \pm 1.4 \mathrm{~A}$ & $3.2 \pm 2.5 \mathrm{~A}$ & $4.4 \pm 3.6 \mathrm{~A}$ \\
7- Cardboard & $6.3 \pm 5.9 \mathrm{~A}$ & $5.7 \pm 3.7 \mathrm{~A}$ & $26.5 \pm 5.3 \mathrm{~B}$ \\
8- Raw/Beany & $11.2 \pm 5.6 \mathrm{~B}$ & $4.9 \pm 3.4 \mathrm{~A}$ & $12.3 \pm 4.2 \mathrm{~A}$ \\
Tastes & & & $4.7 \pm 3.5 \mathrm{~A}$ \\
9- Sweetness & $14.7 \pm 6.1 \mathrm{~A}$ & $29.2 \pm 6.3 \mathrm{C}$ & $5.5 \pm 3.0 \mathrm{~A}$ \\
10- Salty & $8.2 \pm 3.4 \mathrm{~A}$ & $5.3 \pm 2.8 \mathrm{~A}$ & \\
11- Sour & $3.3 \pm 2.3 \mathrm{~A}$ & $5.6 \pm 3.1 \mathrm{~A}$ & $45.1 \pm 4.9 \mathrm{~A}$ \\
12- Bitterness & $5.8 \pm 3.5 \mathrm{~A}$ & & $54.3 \pm 7.3 \mathrm{~A}$ \\
Texture & & $45.9 \pm 7.4 \mathrm{~A}$ & $50.6 \pm 10.2 \mathrm{~A}$ \\
13- Hardness & $47.8 \pm 4.6 \mathrm{~A}$ & $54.9 \pm 8.5 \mathrm{~A}$ & \\
14- Crunchiness & $55.5 \pm 7.6 \mathrm{~A}$ & $49.9 \pm 11.1 \mathrm{~A}$ & \\
15- Tooth pack & $50.9 \pm 10.1 \mathrm{~A}$ & & \\
\hline
\end{tabular}

${ }^{a}$ Mean followed by the same letter within each row are not significantly different at $\alpha=0.05$.

found that the roasted peanutty intensity was 67 and 63 in Roasted Peanuts and Cracker Coated Peanuts, respectively, also in peanut products prepared with American peanuts. In this work, the intensities of roasted peanutty in RP, RP-P and RPA were 51.449 .4 and 49.9 , respectively.

Another important attribute used to characterize the flavor of peanuts is sweetness. This attribute showed an intensity of 14.7 in RP, 29.2 in RP-P and 26.5 in RP-A measured in an unstructured line scale of $150 \mathrm{~mm}$. Grosso and Resurreccion (2002) reported an intensity 7 in sweetness for roasted peanut prepared with American peanuts. The attributes, sweetness and salty had higher intensities in RP-P and RP-A because of their coating layer containing sugar and salt. The intensity ratings of these taste attributes could have influenced the results of consumer acceptability (Table 3).

Oxidized, cardboard and painty flavors are sensory attributes associated with chemical changes occurring during lipid oxidation (Warner et al., 1996; Frankel, 2005). Bett and Boylston (1992) detected that cardboard flavor intensity had a linear increase across storage time in roasted peanuts. Muego-Gnanasekharan and Resurreccion (1992) detected that oxidized and cardboard flavor intensities exhibited a linear increase during storage time in peanut paste. Warner et al. (1996) observed that oxidized flavor intensity increased during storage time in ground roasted peanuts. In this work, the intensity of oxidized and cardboard flavors in RP, RP-P and RP-A were very low because the analyzed products were fresh without storage. This kind of coating in roasted peanuts like honey in honey roasted peanuts improves the stability of the product by making it more resistant to lipid oxidation and the development of rancid flavors (Nepote et al. 2006b). These syrups could be used for increasing the shelf life of roasted peanuts, preventing a loss in sensory and nutritional quality.

The texture sensory attributes, hardness, crunchiness and tooth pack, have an important influence on the acceptability of peanut products (Meilgard et al., 1991). In this work, these three texture attributes did not show significant differences between the peanut products. Therefore the coating layer composed of syrup, sugar and salt did not affect the texture of the final products. Similar results in the intensity ratings of these texture attributes were found by Grosso and Resurrección (2002) in roasted peanuts prepared with American peanuts and by Mestrallet et al. (2004) in roasted peanuts and honey roasted peanuts prepared with Argentinean peanuts.

\section{CONCLUSIONS}

The results of this work indicate that the use of the coatings of prickly pear and "algarrobo" pod syrups in roasted peanuts are acceptable for the consumer. The intensity of roasted peanutty flavor, the more significant attribute for a peanut product, is not affected by the pod syrup coating. For this reason, this new product with a natural coating could be introduced into the market having good nutritional quality due to its main ingredient which is peanuts. 


\section{ACKNOWLEDGMENT}

This work was supported by CONICET, Agencia Córdoba Ciencia and SECYT-UNC.

\section{REFERENCES}

Ahmed EH, Young CT. 1982. Composition, quality, and flavor of peanuts en Pattee HE, Young CT. (Ed). Peanut Science and Technology, 655-688. American Peanut Research and Education Society Inc., Yoakum, TX.

AOAC. 1980. Official Methods of Analysis. Horwitz W. (Ed.), 13th ed., 435-440. Association of Official Analytical Chemists, Washington, DC.

Astudillo L, Schmeda-Hirschmann G, Herrera JP, Cortés M. 2000. Proximate composition and biological activity of Chilean Prosopis species. J Sci Food Agric. 80 (5) 567-573.

Bett KL, Boylston TD. 1992. Effect of storage on roasted peanut quality en St. Angelo AJ. (Ed.) Lipid Oxidation in Food, 322-343. ACS Symposium Series 500, American Chemical Society, Washington DC.

Brannan GL, Koehler PE, Ware GO. 1999. Physicochemical and sensory characteristics of defatted roasted peanuts during storage. Peanut Sci. 26, 4453.

Buckholz LL, Daun H. 1981. Instrumental and sensory characteristics of roasted peanut flavor volatiles en Teranishi R, Barrera-Benitez H. (Ed.) Quality of Selected Fruits and Vegetables, 163-181. ACS Symposium Series 170, American Chemical Society, Washington, DC.

Crippen KL, Vercellotti JR, Lovegren NV, Sanders TH. 1992. Defining roasted peanut flavor quality, Part 2, Correlation of GC volatiles and sensory flavor attributes en Charalambous G. (Ed.) Food Science and Human Nutrition, 211-227. Elsevier Science Publisher BV, Amsterdam.

Demaio P, Karlin UO, Medina M. 2002. Arboles Nativos del Centro de Argentina, 66-119. L.O.L.A (Literature of Latin America), Buenos Aires, Argentina.

Frankel EN. 2005. Lipid Oxidation, 2nd Ed., 1-470. The Oily Press. Bridgewater, England.

Grosso NR, Guzman CA. 1995. Chemical composition of aboriginal peanut $(A$. hypogaea) seeds from Peru. J Agric Food Chem. 43, 102-105.
Grosso NR, Resurreccion AVA. 2002. Predicting consumer acceptance ratings of cracker-coated and roasted peanuts from descriptive analysis and hexanal measurements. J Food Sci 67 (4) 1530-1537.

Johnsen PB, Civille GV, Vercellotti JR, Sanders TH, Dus CA. 1988. Development of a lexicon for the description of peanut flavor. J Sensory Studies 3, 9-17.

Meilgaard M, Civille GV, Carr BT. 1991. Sensory Evaluation Techniques, 2nd Ed., 135-235. CRC Press Inc, Boca Raton, Florida.

Mestrallet MG, Carnacini L, Días MJ, Nepote V, Ryan L, Conci S, Grosso NR. 2004. Honey Roasted Peanuts and Roasted Peanuts from Argentina. Sensorial and Chemical Analyses. Grasas Aceites 55 (4) 401-408. Spain.

Muego-Gnanasekharan KF, Resurrección AVA. 1992. Physicochemical and sensory characteristic of peanut paste stored at different temperatures. J Food Sci. 57, 1385-1389.

Nepote V, Mestrallet MG, Grosso NR. 2004. Natural Antioxidant Effect from Peanut Skins in Honey Roasted Peanuts. J Food Sci. 69 (7) 295-300.

Nepote V, Mestrallet MG, Accietto RH, Galizzi M, Grosso NR. 2006a. Chemical and sensory stability of roasted high-oleic acid peanuts from Argentina. J. Sci. Food Agric. 86, 944-952.

Nepote V, Mestrallet MG, Ryan L, Conci S, Grosso NR. 2006b. Sensorial and Chemical Changes in Honey Roasted Peanuts and Roasted Peanuts Stored under Different Temperatures. J. Sci. Food Agric. 86, 10571063.

Plemmons LE, Resurreccion AVA. 1998. A warm-up sample improves reliability of responses in descriptive analysis. J. Sensory Studies 13, 359-376.

Resurreccion, A. V. A. (1998). Consumer Sensory Testing for Product Development. Aspen Publisher Inc. Gaithersburg, Maryland.

St. Angelo AJ. 1996. Lipid oxidation in food. Critical Reviews in Food Science and Nutrition 36 (3), 175-224.

Warner KJH, Dimick PS, Ziegler GR, Mumma RO, Hollender R. 1996. Flavor-fade and off flavor in ground roasted peanuts as related to selected pyrazines and aldehydes. J. Food Sci. 61, 496-472.

Woodroof JG. 1983. Peanuts. Production, Processing, Products. 3th edn., 8-10. AVI Publishing Company Inc., Westport, CT, USA.

Recibido: 8/11/08 Aceptado: 10/1/08 